\title{
Analysis K-Nearest Neighbor Algorithm for Improving Prediction Student Graduation Time
}

\author{
Rizki Muliono \\ Universitas Medan Area \\ Medan, Indonesia \\ rizkimuliono@gmail.com
}

\author{
Juanda Hakim Lubis \\ Universitas Medan Area \\ Medan, Indonesia \\ juandahakim@gmail.com
}

\author{
Nurul Khairina \\ Universitas Medan Area \\ Medan, Indonesia \\ nurulkhairina27@gmail.com
}

Submitted: Jan 30, 2020

Accepted: Mar 11, 2020

Published: Apr 1, 2020

\begin{abstract}
Higher education plays a major role in improving the quality of education in Indonesia. The BAN-PT institution established by the government has a standard of higher education accreditation and study program accreditation. With the 4.0-based accreditation instrument, it encourages university leaders to improve the quality and quality of their education. One indicator that determines the accreditation of study programs is the timely graduation of students. This study uses the K-Nearest Neighbor algorithm to predict student graduation times. Students' GPA at the time of the seventh semester will be used as training data, and data of students who graduate are used as sample data. K-Nearest Neighbor works in accordance with the given sample data. The results of prediction testing on 60 data for students of 2015-2016, obtained the highest level of accuracy of $98.5 \%$ can be achieved when $\mathrm{k}=3$. Prediction results depend on the pattern of data entered, the more samples and training data used, the calculation of the K-Nearest Neighbor algorithm is also more accurate.
\end{abstract}

Keywords — prediction; graduation time; k-nearest neighbor

\section{INTRODUCTION}

In the Study Program and Higher Education Accreditation Forms, the timely graduation of undergraduate students is one component that has influence (Novianti \& Prasetyo, 2017). To get good grades in accreditation, students are targeted to graduate on time and achieve an average Semester Achievement Index above 3.50 .

According to the graduation data of the Faculty of Engineering, Universitas Medan Area in recent years, the average number of students who complete their studies on time has not yet reached the target. Some problems that often occur that cause students to graduate on time, including low Semester Achievement Index and GPA scores, economic factors, environmental factors, and family.

Prediction of students will graduate on time or not can be noticed since students sit in the seventh semester. Semester Achievement Index sand the number of credits will be a reference to predict the time students graduate. 
Data mining is one of the fields of computer science that focuses on machine learning (Muliono, Muhathir, Khairina, \& Harahap, 2019) (Muliono, 2017). Data mining is used to predict conditions based on data and information (Tang, He, \& Zhang, 2020) (Muliono \& Sembiring, 2019). The K-Nearest Neighbor method uses data classification techniques that are divided into clusters (Agrawal, 2019). Prediction results can be calculated based on the distance closest to the sample data (Gou et al., 2019) (Czumaj \& Sohler, 2020). This research will predict the graduation time of the students with the K-Nearest Neighbor algorithm. As for some previous studies related to this research are as follows:

The Research by (Prasetyo, Kusrini, \& Arief, 2019) uses the K-Nearest Neighbor algorithm to see the interests and talents of students in the field of Information Engineering. This choice of specialization is done by Case Base Reasoning (CBR). The results showed that this algorithm successfully predicted with an accuracy rate of $95.98 \%$ at $\mathrm{K}=7$.

The Research by (Nikmatun \& Waspada, 2019) applies the K-Nearest Neighbor algorithm that refers to Data Mining Knowledge Discovery in Database (KDD). This study classifies courses that determine the time students graduate. The research results obtained a good prediction with an accuracy of $75.95 \%$.

The research by (Hakim, Rizal, \& Ratnasari, 2019) uses the K-Nearest Neighbor algorithm and Roger S. Pressman's waterfall method namely Communication, Planning, Modeling, and Construction. The results showed that the best accuracy was found in testing with the Confusion Matrix, where the accuracy reached $98 \%$.

The Research by (Rohman \& Rochcham, 2019) compares Neural Network, K-Nearest Neighbor and Decision Tree algorithms in predicting student graduation. The results showed that the highest accuracy was found in the K-Nearest Neighbor algorithm which reached $83.66 \%$.

The research by (Purwanto, Kusrini, \& Sudarmawan, 2019) made a comparison of the C.45 algorithm and the K-Nearest Neighbor in predicting the study period of students of Muhammadiyah University in Purwokerto. The results showed that the highest accuracy was found in the K-Nearest Neighbor algorithm which reached $89.14 \%$.

\section{METHODOLOGY}

K-Nearest Neighbor algorithm is a classification method that can classify new data based on the distance of the new data to the closest data/neighbors in data learning (Atma \& Setyanto, 2018) :

The training process is to start input: training data, data transfer label, $\mathrm{k}$, testing data. a. For all testing data, calculate the distance to each training data

b. Determine the training data $\mathrm{k}$ which is the closest distance to the data

c. Testing

d. Check the label of this data

e. Determine the label with the most frequency

f. Enter the testing data to the class with the most frequency

g. Stop

To calculate the distance between two points $\mathrm{x}$ and $y$, you can use the Euclidean distance as follows (Wang et al., 2019)

$$
d\left(X_{1}, Y_{2}\right)=\sum_{I}\left|\frac{n_{1 i}}{n_{1}}-\frac{n_{2 i}}{n_{2}}\right|
$$

Which $\mathrm{X}_{1}, 1=1,2$, is the category attribute, and $\mathrm{n}$ $1 \mathrm{j}-\mathrm{n}_{2 \mathrm{i}}$ represents the corresponding frequency. The closeness between the two cases can be calculated by finding the value of similarity as follows (Rahmatullah \& Utami, 2019)

$$
\operatorname{similarity}(T, S)=\frac{\sum_{i=1}^{n} f\left(T_{i}, S_{i}\right) * w_{i}}{w_{i}}
$$

Description :

q: new case

$\mathrm{s}$ : cases that are in deviation

$\mathrm{n}$ : number of attributes in each case

i: individual attributes between 1 to $\mathrm{n}$

$\mathrm{f}$ : similarity function I between cases $\mathrm{T}$ and $\mathrm{S}$

wi: the weight is given to the i-th attribute

This similarity is expressed by 1 (similar) and 0 (not similar), mathematically, it can be written:

$$
s=\begin{aligned}
& 1 \text { if } x=y \\
& 0 \text { if } x \neq y
\end{aligned}
$$

Giving weights for each attribute can be done by following a few steps below:

1. Input the criteria value of each model (LCS)

2. Input the weights of each criterion (BBT)

3. Calculate normalization from weights (NK)

$$
\begin{gathered}
N K=\frac{\sum_{i=1}^{n}(S B K) x B B T \%}{n} \\
\text { Value }=\frac{\sum N K}{N}
\end{gathered}
$$

To test the accuracy of the predicted performance measurement of the K-NN algorithm, it is performed by 
comparing the results of the classification algorithm prediction with the target value of the testing data variable as the actual data. So logically, it can be concluded that the performance of the algorithm is as follows:

$$
\text { Accuracy }=\frac{\text { the predicted amount is correct }}{\text { total number of instances }} \times 100 \%
$$

\section{RESULT AND DISCUSSION}

The research test was conducted on the data of 20 students of the Civil Engineering Study Program in the seventh semester of 2015. Detailed research results can be seen as follows:

Table 1. Accuracy Comparison of Predictive Predicate Values with KNN and Real Data K = 5

\begin{tabular}{|c|c|c|c|c|}
\hline No & NPM & $\begin{array}{c}\text { Prediction } \\
\text { KNN }\end{array}$ & Result & Point \\
\hline 1 & 158110001 & Correct & Correct & 1 \\
\hline 2 & 158110002 & Incorrect & Incorrect & 1 \\
\hline 3 & 158110003 & Incorrect & Incorrect & 1 \\
\hline 4 & 158110005 & Incorrect & Incorrect & 1 \\
\hline 5 & 158110006 & Correct & Correct & 1 \\
\hline 6 & 158110007 & Incorrect & Incorrect & 1 \\
\hline 7 & 158110010 & Correct & Correct & 1 \\
\hline 8 & 158110012 & Incorrect & Incorrect & 1 \\
\hline 9 & 158110015 & Incorrect & Incorrect & 1 \\
\hline 10 & 158110017 & Correct & Correct & 1 \\
\hline 11 & 158110018 & Incorrect & Incorrect & 1 \\
\hline 12 & 158110020 & Incorrect & Correct & 0 \\
\hline 13 & 158110022 & Correct & Correct & 1 \\
\hline 14 & 158110023 & Incorrect & Incorrect & 1 \\
\hline 15 & 158110024 & Incorrect & Incorrect & 1 \\
\hline 16 & 158110025 & Correct & Correct & 1 \\
\hline 17 & 158110027 & Correct & Correct & 1 \\
\hline 18 & 158110028 & Incorrect & Incorrect & 1 \\
\hline 19 & 158110029 & Incorrect & Incorrect & 1 \\
\hline 20 & 158110030 & Incorrect & Incorrect & 1 \\
\hline
\end{tabular}

From the results of experiments conducted to see the accuracy of the comparison of training data to the results of algorithms found the results with timely conclusions at K1 and K2 = 176, while K3-K5 = 197 .

Table 2. Accuracy Levels

\begin{tabular}{|c|c|c|c|}
\hline K & $\begin{array}{c}\text { Accuracy } \\
\text { Levels }\end{array}$ & $\begin{array}{c}\text { Accuracy } \\
\text { Levels }\end{array}$ & Conclusion \\
\hline
\end{tabular}

\begin{tabular}{|c|c|c|c|}
\hline K1 & $\begin{array}{c}\text { Confusion } \\
\text { Matrix }\end{array}$ & $\begin{array}{c}\text { ROC } \\
\text { Curve }\end{array}$ & \\
\hline K2 & $88,0 \%$ & 0.880 & $\begin{array}{c}\text { Good } \\
\text { Classification }\end{array}$ \\
\hline K3 & $98,5 \%$ & 0,985 & $\begin{array}{c}\text { Good } \\
\text { Classification }\end{array}$ \\
\hline K4 & $98,5 \%$ & 0,985 & $\begin{array}{c}\text { Excellent } \\
\text { Classification }\end{array}$ \\
\hline K5 & $98,5 \%$ & 0,985 & $\begin{array}{c}\text { Excellent } \\
\text { Classification }\end{array}$ \\
\hline
\end{tabular}

The higher the $\mathrm{K}$ value, the better the accuracy level of K-NN algorithm predictions on 2015 student training data, the conclusion is from the $\mathrm{K} 1-\mathrm{K} 5$ trial results of K-NN algorithm classification results in the accuracy of student graduation prediction by comparing the Rael scores and the prediction results can be concluded as Excellent Classification

Next is to make a prediction on time for the 2016 data of the 2016 students' whip, which will be tested from $\mathrm{K} 1-\mathrm{K} 5$.

Table 3. Predicted Results for 2016 Stock Data of Civil Engineering Study Program

\begin{tabular}{|c|c|c|c|c|c|c|c|c|c|}
\hline $\mathbf{N P M}$ & $\begin{array}{c}\text { SAI } \\
\mathbf{1}\end{array}$ & $\begin{array}{c}\text { SAI } \\
\mathbf{2}\end{array}$ & $\begin{array}{c}\mathbf{S A I} \\
\mathbf{3}\end{array}$ & $\begin{array}{c}\text { SAI } \\
\mathbf{4}\end{array}$ & $\begin{array}{c}\text { SAI } \\
\mathbf{5}\end{array}$ & $\begin{array}{c}\text { SAI } \\
\mathbf{6}\end{array}$ & $\begin{array}{c}\mathbf{S A I} \\
\mathbf{7}\end{array}$ & $\begin{array}{c}\text { SKS } \\
\text { Passed }\end{array}$ & Prediction \\
\hline $\begin{array}{c}16811 \\
0003\end{array}$ & 3.25 & 3.29 & 3.82 & 3.53 & 3.53 & 3.82 & 3.53 & 136 & Correct \\
\hline $\begin{array}{c}16811 \\
0005\end{array}$ & 3.61 & 3.47 & 2.04 & 1.75 & 2.67 & 2.55 & 3.37 & 122 & Incorrect \\
\hline $\begin{array}{c}16811 \\
0009\end{array}$ & 3.38 & 3.13 & 2.55 & 3.37 & 3.05 & 3.61 & 3.29 & 132 & Incorrect \\
\hline $\begin{array}{c}16811 \\
0011\end{array}$ & 3.39 & 3.13 & 3.47 & 2.95 & 2.67 & 3.82 & 2.55 & 132 & Incorrect \\
\hline $\begin{array}{c}16811 \\
0012\end{array}$ & 3.61 & 3.03 & 3.37 & 3.42 & 3.47 & 3.76 & 2.67 & 136 & Correct \\
\hline $\begin{array}{c}16811 \\
0016\end{array}$ & 3.29 & 3.71 & 2.88 & 3.05 & 3.53 & 2.88 & 3.05 & 132 & Incorrect \\
\hline $\begin{array}{c}16811 \\
0017\end{array}$ & 3.24 & 3.13 & 3.61 & 3.29 & 2.55 & 3.05 & 3.53 & 132 & Incorrect \\
\hline $\begin{array}{c}16811 \\
0022\end{array}$ & 3.71 & 3.29 & 3.05 & 3.53 & 3.05 & 3.82 & 3.53 & 136 & Correct \\
\hline $\begin{array}{c}16811 \\
0026\end{array}$ & 3.61 & 3.47 & 2.04 & 1.75 & 2.67 & 2.55 & 3.37 & 122 & Incorrect \\
\hline $\begin{array}{c}16811 \\
0028\end{array}$ & 3.61 & 3.47 & 2.04 & 1.75 & 2.67 & 2.55 & 3.37 & 122 & Incorrect \\
\hline
\end{tabular}


The sample data of 200 data consists of the 2015 data stick and the data to be predicted is the 2016 data canopy of 60 data with a ratio of $70 \%$ training data and $30 \%$ testing data. From the results of prediction experiments on 2016 data, there are 60 data with timely prediction results that can be seen in the following table:

Table 4. Predicted Results of 2016 Whamb Graduation

\begin{tabular}{|c|c|c|}
\hline $\mathbf{K}$ & Correct & Incorrect \\
\hline K1 & 25 & 35 \\
\hline K2 & 25 & 35 \\
\hline K3 & 16 & 44 \\
\hline K4 & 16 & 44 \\
\hline K5 & 16 & 44 \\
\hline
\end{tabular}

\section{CONCLUSION AND SUgGeStion}

\section{A. Conclusion}

The conclusions of this study are as follows:

1. In the case of predictions of 2015 student data on the whip of K-NN algorithm the better level of K3 and so on is $98.5 \%$ from the previous $\mathrm{K} 88 \%$ increased by $1.5 \%$

2. In predictions, 60 of the 2016 canopy data shows the condition of predicted data at $\mathrm{K} 1$ and $\mathrm{K} 2=25$ On-Time, while at K3 - K5 = 16 On Time.

3. The state of the predicted results depends on the distribution of data patterns, the more data the better the calculation of the K-NN algorithm

4. The more data the application transfers, the less time it takes to process distance calculations.

\section{B. Suggestion}

It is hoped that the $\mathrm{K}-\mathrm{NN}$ prediction application based on web-based research results can be used by the Faculty to assist monitoring as an EWS (Early Warning System) for the academic development of students in the Faculty of Engineering, Universitas Medan Area in particular.

\section{ACKNOWLEDGMENT}

The researcher would like to thank the Universitas Medan Area for funding the DIYA Research to completion. Hopefully, this research is not only useful for the Universitas Medan Area but also can be useful for the development of science and society.

\section{REFERENCES}

Agrawal, R. (2019). Integrated Parallel K-Nearest
Neighbor Algorithm. In Smart Intelligent Computing and Applications (p. 479). Springer Singapore. https://doi.org/10.1007/978-981-131921-1

Atma, Y. D., \& Setyanto, A. (2018). Perbandingan Algoritma C4.5 dan K-NN dalam Identifikasi Mahasiswa Berpotensi Drop Out. Metik Jurnal, 2(2), 31-37.

Czumaj, A., \& Sohler, C. (2020). Sublinear time approximation of the cost of a metric $\mathrm{k}$-nearest. In Society for Industrial and Applied Mathematics (pp. 2973-2992).

Gou, J., Ma, H., Ou, W., Zeng, S., Rao, Y., \& Yang, H. (2019). A Generalized Mean Distance-Based KNearest Neighbor Classifier. Expert Systems with Applications, 115, 3-24. https://doi.org/10.1016/j.eswa.2018.08.021

Hakim, L. A. R., Rizal, A. A., \& Ratnasari, D. (2019). Aplikasi Prediksi Kelulusan Mahasiswa Berbasis K-Nearest Neighbor (K-NN). JTIM : Jurnal Teknologi Informasi Dan Multimedia, 1(1), 30 36. https://doi.org/10.35746/jtim.v1i1.11

Muliono, R. (2017). Implementasi Algoritma Apriori Pada Data Benchmark Kosarak Dan Mushrooms. Journal of Informatics and Telecommunication Engineering, 1(1), 34-41.

Muliono, R., Muhathir, Khairina, N., \& Harahap, M. K. (2019). Analysis of Frequent Itemsets Mining Algorithm Againts Models of Different Datasets. In 1 st International Conference of SNIKOM 2018 (pp. 1-5). https://doi.org/10.1088/17426596/1361/1/012036

Muliono, R., \& Sembiring, Z. (2019). Data Mining Clustering Menggunakan Algoritma K-Means Untuk Klasterisasi Tingkat Tridarma Pengajaran Dosen. CESS (Journal Of Computer Engineering, System And Science), 4(2), 272-279.

Nikmatun, I. A., \& Waspada, I. (2019). Implementasi Data Mining untuk Klasifikasi Masa Studi Mahasiswa Menggunakan Algoritma K-Nearest Neighbor. Jurnal Simetris, 10(2), 421-432.

Novianti, A. G., \& Prasetyo, D. (2017). Penerapan Algoritma K-Nearest Neighbor (K-NN) untuk Prediksi Waktu Kelulusan Mahasiswa. In Seminar Nasional APTIKOM(SEMNASTIKOM) (pp. 108-113).

Prasetyo, A., Kusrini, \& Arief, M. R. (2019). Penerapan Algoritma K Nearest Neighbor untuk Rekomendasi Minat Konsentrasi di Program Studi Teknik Informatika Universtias PGRI Yogyakarta. Informasi Interaktif, 4(1), 1-6.

Purwanto, E., Kusrini, \& Sudarmawan. (2019). Prediksi Kelulusan Tepat Waktu Menggunakan Metode C4 . 5 DAN K - NN (Studi Kasus : Mahasiswa 
Program Studi S1 Ilmu Farmasi, Fakultas Universitas Muhammadiyah Purwokerto ). TECHNO, 20(2), 131-142.

Rahmatullah, S., \& Utami, E. (2019). Prediksi Tingkat Kelulusan Tepat Waktu dengan Metode Naive Bayes dan K-Nearest Neighbor. Jurnal Informasi Dan Komputer, 7(1), 7-16.

Rohman, A., \& Rochcham, M. (2019). Komparasi Metode Klasifikasi Data Mining untuk Prediksi Kelulusan Mahasiswa. Jurnal Neo Teknika, 5(1), 23-31.

Tang, B., He, H., \& Zhang, S. (2020). MCENN: A Variant of Extended Nearest Neighbor Method for Pattern Recognition. Pattern Recognition
Letters, $1-10$. https://doi.org/10.1016/j.patrec.2020.01.015

Wang, Y., Wang, R., Li, D., Adu-Gyamfi, D., Tian, K., \& Zhu, Y. (2019). Improved Handwritten Digit Recognition using Quantum K-Nearest Neighbor Algorithm. International Journal of Theoretical Physics, $58(7)$,

2331-2340. https://doi.org/10.1007/s10773-019-04124-5 